UDC $504.05 ; 626 / 627$

Dmytro V. Stefanyshyn ${ }^{1,2}$, D. S. (Engineering), Lead researcher, Professor of Department ORCID ID: 0000-0002-7620-1613e-mail: d.v.stefanyshyn@nuwm.edu.ua

Yurii S. Vlasiuk ${ }^{2}$, Postgraduate student

ORCID ID: 0000-0002-6359-733X e-mail: y.s.vlasiuk@nuwm.edu.ua

${ }^{1}$ Institute of Telecommunications and Global Information Space of NASU, Kyiv, Ukraine

${ }^{2}$ National University of Water and Environmental Engineering, Rivne, Ukraine

\title{
SOME CRITICAL COMMENTS ON THE QUALITY OF ENVIRONMENTAL IMPACT ASSESSMENT REPORTS FOR SMALL HYDROPOWER PLANTS IN UKRAINE
}

\begin{abstract}
Nowadays, small hydropower in Ukraine has a small share in the national energy balance. However, in Ukraine small hydropower has been still developing, but its development is largely spontaneous, not accompanied by scientific and technical researches of small rivers, as well as an appropriate analysis of the impact of small hydropower plants on the environment. As a result, there is an increasing resistance to the building of new hydropower plants in the country by environmentalists, activists and the public.

The issue of small hydropower in our country has become a new topical challenge in connection with the adoption in 2017 of the Act of Ukraine "On Environmental Impact Assessment". According to this Act, all hydropower plants on rivers, regardless of their capacity, including small hydropower plants, are classified as planned activities and objects that can have a significant environmental impact and are subject to environmental impact assessment.

Since 2017, in accordance with the Act, a large number of environmental impact assessment reports have been submitted to the Unified Register concerning planned activities related to the construction of new small hydropower plants, which were prepared by various entities, including universities.

The main objective of the research was to analyze the reports presented in the Unified Register and the formulation of practical comments on the quality of their preparation, the accuracy and completeness of information on the environmental impacts of the planned small hydropower plants. The purpose of the article is to familiarize professionals in the various fields of knowledge relevant to the issue, in particular, hydraulic engineers, hydropower engineers, environmentalists, as well as potential investors in small hydropower, public activists and the general public with these remarks.

Totally, 16 of reports were analyzed in detail. The main shortcomings of the performed environmental impact assessments of the new small hydropower plants planned to build were noted, including the lack of proper analysis of alternatives and scientifically sound forecasts, the incompetence of experts in the issues related to the environmental impacts of hydraulic structures. Practical recommendations were formulated that can help improve the quality of the environmental impact assessment of small hydropower plants, with the aim of avoiding environmentally hazardous decisions, taking into account the various environmental and social risks associated with small hydropower facilities.
\end{abstract}

Keywords: feasibility; hydrotechnical construction; environmental impact assessment report; small hydropower; small hydropower plants; planned activity

(C) D.V. Stefanyshyn, Yu.S. Vlasiuk, 2019 


\title{
Д.В. Стефанишин ${ }^{1,2}$, Ю.С. Власюк ${ }^{2}$
}

${ }^{1}$ Інститут телекомунікацій і глобального інформаційного простору НАН України, м. Київ, Україна

${ }^{2}$ Національний університет водного господарства та природокористування, м. Рівне, Україна

\section{ДЕЯКІ КРИТИЧНІ ЗАУВАЖЕННЯ ЩОДО ЯКОСТІ ЗВІТІВ 3 ОЦІНКИ ВПЛИВУ НА ДОВКІЛЛЯ МАЛИХ ГІДРОЕЛЕКТРОСТАНЦІЙ В УКРАЇНІ}

\begin{abstract}
Анотація. Наразі в Украӥні мала гідроенергетика має незначну долю в енергобалансі. Втім, їі розвиток в Україні відбувається, але здебільшого стихійно, не супроводжуючись науковими та технічними дослідженнями малих річок, аналізом впливу малих гідроелектростаниій на довкілля. В результаті зростає спротив будівництву нових малих гідроелектростанцій в країні зі сторони екологів, активістів та громадськості.

Проблема малої гідроенергетики в країні набула нового звучання у зв'язку з прийняттям в 2017 р. Закону Украӥни «Про оиінку впливу на довкілля». Згідно з иим Законом всі гідроелектростаниії на річках незалежно від їх потужності, включно $i$ малі гідроелектростаниії, віднесено до видів планованої діяльності та об’єктів, які можуть мати значний вплив на довкілля та підлягають оичіні впливу на довкілля.
\end{abstract}

32017 року, у відповідності з прийнятим Законом, в єдиний реєстр надійшла велика кількість звітів з оиінки впливу на довкілля, підготовлених різними суб'єктами господарювання, в тому числі $і$ університетами, планованої діяльності, пов'язаної з будівництвом нових малих гідроелектростаниій.

Основною задачею проведених нами досліджень був аналіз представлених в єдиному реєстрі звітів з формулюванням практичних зауважень щодо якості їх підготовки на предмет достовірності та повноти інформачії про впливи запланованих малих гідроелектростаниій на довкілля. Мета иієї статті полягає в ознайомленні фахівців з різних галузей знань, дотичних до проблеми, зокрема інженерів-гідротехніків, гідроенергетиків, екологів, а також $i$ потениійних інвесторів у малу гідроенергетику, громадських активістів та широкої громадськості з цими зауваженнями.

Всього детально було проаналізовано 16 звітів. Відмічено основні недоліки виконаних оцінок впливу на довкілля планованих до будівництва нових малих гідроелектростаниій, серед яких відсутність належного аналізу альтернатив та науково обтрунтованих прогнозів, некомпетентність експертів в питаннях, що стосуються впливів гідротехнічних споруд на довкілля. Сформульовано практичні рекомендації, які можуть сприяти підвищенню якості оцінки впливу на довкілля малих гідроелектростанцій в країні, з метою недопущення екологічно та соціально небезпечних рімень, врахування різних екологічних та сочіальних ризиків, пов'язаних з об 'єктами малої гідроенергетики.

Ключові слова: дочільність; гідротехнічне будівництво; звіт з очінки виливу на довкілля; мала гідроенергетика; малі гідроелектростанції; планована діяльність

\section{Вступ}

Терміном «малі гідроелектростанції» (малі ГЕС, МГЕС) в світі прийнято називати гідроенергетичні установки потужністю до 10-30 МВт [1]. В Україні 
до МГЕС відносять ГЕС потужністю до 10 МВт. Серед них МГЕС зі встановленою потужністю до 0,2 МВт відносять до категорії мікро ГЕС, до $1 \mathrm{MB}$ - міні ГЕС, від 1 до 10 МВт - власне малих ГЕС $[1,2]$.

Вітчизняна мала гідроенергетика має незначну частку в національному енергобалансі (близько 0,15\% на 2015 р. [3]) і складну історію становлення, розвитку, занепаду та відновлення - завдяки впровадженню в середині 90-х років минулого століття «зеленого» тарифу [2]. На 2018 р. сумарна встановлена потужність МГЕС в країні склала лише 99 МВт [4], що значно менше сумарної встановленої потужності таких альтернативних джерел «малої» відновлюваної електроенергетики, як сонячні електростанції (СЕС) домогосподарств (157 МВт) та установки на біомасі і біогазі (103 МВт).

За дев'ять місяців 2019 р. ситуація зі введенням нових потужностей електрогенерації у відновлюваній «зеленій» енергетиці в країні ще більше змінилася не на користь малої гідроенергетики. Так, за повідомленням голови Державного агентства 3 енергоефективності та енергозбереження України Сергія Савчука [5], за цей період у відновлюваній енергетиці, де діє «зелений» тариф, введено такі нові потужності: понад 2000 МВт - на СЕС; майже $400 \mathrm{MBT}$ - на вітрових електростанціях (ВЕС); близько $120 \mathrm{MBT}$ - на СЕС домогосподарств (і це лише за 6 місяців ц.р.); 24 МВт привнесли в об'єднану енергосистему (ОЕС) країни біогазові установки; 13 МВт - об'єкти малої гідроенергетики та 4 МВт - об'єкти на біомасі.

Загалом в структурі альтернативної відновлюваної енергетики в країні (без великої гідроенергетики) частка малої гідроенергетики знизилася $343 \%$ в 2010 р. до 4,35\% в 2018 р. i, скоріше за все, як показує і вітчизняна, і світова практика, й надалі продовжуватиме знижуватися. В розрізі сумарної встановленої потужності вітчизняної гідроенергетики на 2018 р. частка малої гідроенергетики склала близько 1,6\% [4]. Очікується, що зі введенням нових потужностей на Дністровській ГАЕС, 3 модернізацією Дніпровського каскаду ГЕС та побудовою Каховської ГЕС-2 можливе подальше зниження частки, яку має мала гідроенергетика і у вітчизняній гідроенергетиці.

Незначний приріст встановленої потужності у вітчизняній малій гідроенергетиці в останні роки може пояснюватися і тим, що в Україні мала гідроенергетика викликає значний спротив подальшому розвитку 3 боку екологів, громадських активістів та місцевих громад [2, 6-8].

Звичайно, у вітчизняної малої гідроенергетики є не лише «противники», а й «прихильники». Серед прихильників малої гідрогенерації, наприклад, варто згадати новопризначеного міністра енергетики та захисту довкілля України Олексія Оржеля. В своїй статті в газеті «Економічна правда» від 16 жовтня 2015 р. [7] майбутній міністр виступив на захист вітчизняної гідроенергетики, в тому числі і малої гідроенергетики. Велику гідрогенерацію в статті було названо «найекологічнішою серед усіх інших форм традиційних способів енерговиробництва». В свою чергу щодо малої гідроенергетики було написано таке: «Сучасні турбіни, виготовлені відповідно до стандартів захисту навколишнього середовища, насичують воду киснем, що сприяє збереженню іхтіофауни, запобігають утворенню паводків, не допускають забруднення водойм завдяки фільтрам», « ... нижче за течією очищена фільтрами i збагачена повітрям вода річки відтворює повноцінне русло», «на противагу великій мала гідроенергетика має переваги щодо екологічності». 
В той же час особи й організації, що виступають проти будівництва нових МГЕС в країні, в статті [7] було звинувачено в маніпуляціях і чорному піарі. Наприклад, такі звинувачення стосувались «начебто експертів українського представництва Всесвітнього фонду дикої природи - WWF, які надають непрофесійні висновки для отримання грантових грошей та спотворюють інформацію, дискредитуючи WWF». Негативні оцінки в статті [7] дісталися i «зеленому туризму», як одній 3 можливих альтернатив розвитку малої гідроенергетики, - через «шкідливий вплив власне самого туристичного бізнесу на природу, про перетворення місць заповідної природи на галявини чи долини розваг для туристів або на промислові мисливські угіддя».

Для порівняння, офіційну позицію WWF щодо малої гідроенергетики в Україні, однієї з найбільш толерантних до малої гідроенергетики в країні організацій-опонентів, викладено в [8], де, зокрема, наголошується, що «масштабне неконтрольоване будівництво об'єктів МГЕС в Україні в останні роки призводить до зникнення унікальних видів риби та більшості водних організмів, погіршення якості води в річках, зміни гідроморфологічних режимів, осушення річок, в окремих регіонах створює соціальну напругу та може призвести до екологічної катастрофи».

Можливо, з 2015 р. [7] думка пана Оржеля щодо будівництва нових МГЕС в Україні дещо змінилася. Втім, навіть якщо вона залишилась і незмінною, то згідно 3 прийнятим в 2017 р. Законом України «Про оцінку впливу на довкілля» [9] (далі - Закон про ОВД) всі нові МГЕС підлягають оцінці впливу на довкілля як види планованої діяльності та об'єкти, «які можуть мати значний вплив на довкілля» (див. Статтю 3 Закону в частині 3, де серед об' єктів енергетичної промисловості, «які можуть мати значний вплив на довкілля та підлягають оцінці впливу на довкілля» вказано «гідроелектростанції на річках незалежно від потужності»). Тобто, за чинним Законом [9], навіть мікро ГЕС, потужністю до 0,2 МВт, визнано об'єктами, які можуть мати значний, в тому числі і негативний, вплив на довкілля.

\section{Загальна постановка задачі досліджень та мета статті}

Як відомо, гідроенергетика використовує відновлюваний енергоресурс i, безумовно, сприяє енергозбереженню. Серед інших джерел електрогенерації, що натепер використовують відновлюваний енергоресурс (СEC, ВEС тощо), гідроенергетика характеризується ще й найвищим коефіцієнтом корисної дії устаткування $(0,7 \ldots 0,9$ і вище) та високою маневреністю $[2,10]$, що наділяє іiі додатковими перевагами.

В свою чергу до важливих переваг МГЕС, в порівнянні з ГЕС більшої потужності, відносяться: порівняно невеликий об'єм інвестицій і більш короткий термін будівництва, що дозволяє прискорити отримання прибутку приватними інвесторами; можливість використовувати гідропотенціал численних малих рік та приток; близькість до індивідуального споживача, який водночас може бути і власником МГЕС; можливість забезпечення електропостачання віддалених від загальних електромереж поселень [1-3, 10].

Втім, гідрогенерація може мати значний негативний вплив на довкілля, водні екосистеми та екопослуги, як на локальному, так і на басейновому рівні, на чому, зокрема, наголошується і в Директивах Європейського Союзу (СС) (Директиви 2001/80/EC та 2010/75/EU), які мають за мету розвиток 
енергозберігаючих технологій та використання відновлюваних джерел енергії i які зобов'язалась виконувати i Україна, приєднавшись в 2010 p. до Європейського Енергетичного співтовариства [11]. При цьому, на відміну від гідроресурсу (стік води, напір), що використовується для вироблення електроенергії на ГЕС, який можна розглядати як такий, що відновлюється, екосистемні ресурси річок, особливо малих і середніх, на яких переважно будуються й експлуатуються МГЕС, не відновлюються і є вичерпними. В Директивах СС вказується, що розвиток гідроенергетики, в тому числі і малої, як потенційно небезпечної для навколишнього середовища технології електрогенерації, має обмежуватися і відбуватися лише за умови вироблення прозорої і збалансованої державної політики, узгодженої з екологічним національним та міжнародним законодавством [12]. Таким чином, питання доцільності будівництва чи відновлення кожної конкретної МГЕС, як і розвитку малої гідроенергетики в країні в цілому, не може розглядатися лише в контексті економічного інтересу - чи то приватного, чи державного. Відповідно, Закон про ОВД [9] має сприяти вирішенню проблеми доцільності діяльності, пов'язаної з будівництвом і експлуатацією нових МГЕС.

Згідно з цим Законом оцінка впливу на довкілля (ОВД) - це процедура, що передбачає ряд дій, серед яких «підготовку суб'єктом господарювання звіту 3 оцінки впливу на довкілля» (далі, звіт з ОВД) [9].

Законом [9] регламентується склад матеріалів звіту з ОВД (всього в звіті передбачено 13 обов'язкових розділів), згідно 3 яким «Оцінка впливу на довкілля здійснюється 3 дотриманням вимог законодавства про охорону навколишнього природного середовища, з урахуванням стану довкілля в місці, де планується провадити плановану діяльність, екологічних ризиків i прогнозів, перспектив соціально-економічного розвитку регіону, потужності та видів сукупного впливу (прямого та опосередкованого) на довкілля, у тому числі з урахуванням впливу наявних об'єктів, планованої діяльності та об'єктів, щодо яких отримано рішення про провадження планованої діяльності або розглядається питання про прийняття таких рішень». У відповідності 3 Законом «Суб’єкт господарювання забезпечує підготовку звіту 3 оцінки впливу на довкілля і несе відповідальність за достовірність наведеної у звіті інформації згідно з законодавством».

Основною задачею проведених нами досліджень був аналіз матеріалів, представлених згідно з Законом [9] в Сдиному Реєстрі [13] звітів з ОВД, та формулювання найбільш типових зауважень щодо об'єктивності ОВД планів будівництва нових МГЕС в країні в контексті можливості обгрунтування доцільності відповідної планованої діяльності. Для аналізу було відібрано звіти, які готувалися різними суб'єктами господарювання, в тому числі університетами та представниками проектних організацій. Метою статті $\epsilon$ ознайомлення інженерів-гідротехніків, гідроенергетиків, екологів, а також i потенційних інвесторів у малу гідроенергетику, активістів та широкої громадськості з результатами проведеного нами аналізу. Крім того, в статті формулюються i деякі практичні рекомендації, які можуть посприяти підвищенню якості виконання ОВД для нових МГЕС, що плануються до будівництва, 3 метою недопущення екологічно та соціально небезпечних рішень, врахування різних екологічних та соціальних ризиків, пов'язаних 3 об'єктами малої гідроенергетики. 


\section{Матеріали для аналізу}

Серед численних звітів з ОВД МГЕС, представлених в Єдиному реєстрі [13], які нами було розглянуто в дослідженні, виділимо наступні.

1). Звіт з ОВД будівництва мікро ГЕС «Липицька МГЕС» встановленою потужністю 200 кВт на р. Дністер в Миколаївському районі Львівської обл. (реєстраційний номер справи в реєстрі з ОВД №2018614992/2121). Звіт було підготовлено ТОВ «Вотерструм» (директор В.В. Крока). Після виявлення громадськістю грубих порушень Закону з ОВД звіт було відкликано.

2). Звіт з ОВД будівництва мікро ГЕС встановленою потужністю 85 кВт на p. Серет в с. Мишковичі, Тернопільського району Тернопільської обл. (справа в Реєстрі №20187251324). Звіт було підготовлено ПМП «Люкс» (директор Дерень Р.М.). За результатами громадського обговорення та розгляду звіту в Управлінні екології та природних ресурсів Тернопільської ОДА було відмовлено у видачі висновку з закриттям справи.

3). Два звіти 3 ОВД для ТОВ «Гідроресурс-Шопурка» (директор В.М. Сегедій) будівництва і експлуатації на р. Шопурка в смт Кобилецька Поляна, Рахівського району Закарпатської обл. двох МГЕС встановленою потужністю до 999 кВт кожна: в урочищі Підпорей (справа в Реєстрі №201853708) та в урочищі Квасний (справа в Реєстрі №201853709). Обидва звіти було підготовлено ТОВ «НП «Експертний Центр» (директор Л.П. Крадожон).

4). Звіт 3 ОВД будівництва Добротвірської МГЕС встановленою потужністю 1 МВт на р. Західний Буг в с. Старий Добротвір, Кам'янкаБузького району Львівської обл. (справа в Реєстрі №2018613978). Звіт було підготовлено ТзОВ «Компанія «Центр ЛТД» (директор О.В. Бота) для ТзОВ «Акваресурсенерго». Планована діяльність має здійснюватися в межах діючих напірних споруд (земляної греблі) Добротвірського гідровузла, водосховище якого використовується Добротвірською ТЕС.

5). Два звіти з ОВД для ТОВ «Енергія Гір плюс» проектів будівництва двох МГЕС встановленою потужністю до 999 кВт кожна на р. Шопурка в Рахівському районі Закарпатської обл.: №1 в межах смт Великий Бичків (справа в Реєстрі №2018530883) та №2 за межами селища В. Бичків (справа №2018530884). Обидва звіти було підготовлено в Івано-Франківському національному технічному університеті нафти і газу (ІФНТУНГ) за авторством д. т. н., проф. Я.О. Адаменка, д. т. н., проф. Л.М. Архипової, д. т. н., проф. О.М. Мандрика, а також за участі д. ф.-м. н., проф. С.С. Попа з Ужгородського національного університету (УжНУ).

6). Три звіти 3 ОВД для ТзОВ «Гідроресурс-Тересва» (директор В.М. Сегедій) будівництва каскаду 3 трьох малих ГЕС на р. Тересва в Тячівському районі Закарпатської обл. у складі: МГЕС-1 в с. Калини, встановленою потужністю до 3500 кВт (справа в Реєстрі №2018426677); МГЕС-2 в с. Калини, встановленою потужністю до 2400 кВт (справа в Реєстрі №2018426678); МГЕС в с. Бедевля встановленою потужністю до 5100 кВТ (справа в Реєстрі №2018426679). Всі три звіти було підготовлено ТОВ «НП «Експертний Центр» (директор Л.П. Крадожон).

7). Звіт з ОВД для ТОВ «Альтернатив електрик» (директор Л.І. Гольштейн) будівництва і експлуатації міні ГЕС встановленою потужністю до 1 МВт на річці Шопурка в смт Великий Бичків, Рахівського району Закарпатської обл. 
(справа в Реєстрі № 2018517802). Звіт було підготовлено ПБМП «СтроїтельІІ» (технічний директор В.В. Галат).

8). Чотири звіти 3 ОВД для ТзОВ «Свидовець Енерго» (директор О.М. Савицький) будівництва та експлуатації чотирьох міні ГЕС встановленою потужністю до 1 МВт кожна на р. Шопурка в смт Великий Бичків, Рахівського району Закарпатської обл.: МГЕС-4 (справа в Реєстрі №2018517801); МГЕС-3 (справа в Реєстрі №2018517800); МГЕС-2 (справа №2018517799); МГЕС-1 (справа в Реєстрі 2018517798). Всі чотири звіти було підготовлено ПБМП «Строїтель-ІІ» (технічний директор В.В. Галат).

9). Звіт з ОВД для ТОВ «БАЛФОРД Україна» (керівник В.В. Васильова, основний вид економічної діяльності ТОВ - оптова торгівля парфумними та косметичними товарами) будівництва малої гідроелектростанції потужністю до 2 МВт на річці Стрий біля с. Довге, Дрогобицького району Львівської обл. (справа в реєстрі №20181252331). Звіт було підготовлено інженеромпроектувальником Ю.М. Сідляром.

Всі перераховані вище звіти було детально вивчено, за їх матеріалами було складено зауваження, які було направлено у відповідні уповноважені органи для ознайомлення в межах громадського обговорення.

\section{Викладення основних положень статті та їх аналіз}

Проаналізовані звіти з ОВД (всього - 16) можна розділити на дві групи.

Перша група - це звіти, які відзначаються недбалим виконанням і значною мірою не відповідають формальним вимогам Закону про ОВД, зокрема, за складом матеріалів. Серед них - звіт з ОВД будівництва Липицької МГЕС на p. Дністер, звіт з ОВД будівництва МГЕС на р. Серет в с. Мишковичі та звіт 3 ОВД будівництва Добротвірської МГЕС на р. Західний Буг. Матеріали 3 різної проблематики впливу на довкілля планованої діяльності в цих звітах перемішано, в звітах мають місце постійні повторення та суперечності, які заважають ознайомленню зі звітами по суті.

Наприклад, в звіті з ОВД будівництва Липицької МГЕС на одній сторінці тексту вказується, що «Земельна ділянка, на якій планується проводити планову діяльність розташована на р. Дністер, на лівому березі»; на іншій сторінці - «Земельна ділянка, на якій планується проводити планову діяльність розташована на р. Дністер, на правому березі». Спочатку «Швидкість води на водозабірній споруді МГЕС не перевищує 0,8 м/с, що забезпечує можливість рибі не потрапляти на гідроагрегати», далі по тексту - «Швидкість води на водозабірній споруді МГЕС не перевищує 0,6 м/с, що забезпечує можливість рибі не потрапляти на гідроагрегати». В звіті наводилася також інформація, що жодним чином не стосується планованої діяльності на р. Дністер у заявленому створі, зокрема інформація, яка має відношення до басейнів інших річок (Західного Бугу, Сяну, Стиру).

В звіті з ОВД будівництва МГЕС на р. Серет в с. Мишковичі на титульній сторінці навіть не вказується, на якій річці і де саме має будуватися МГЕС. При цьому значна частина інформації, що подається в звіті, була запозичена зі звіту з ОВД будівництва Липицької МГЕС на Дністрі.

В звіті з ОВД будівництва Добротвірської МГЕС відсутній окремий розділ, в якому має бути викладено «стислий зміст програм моніторингу та контролю щодо впливу на довкілля під час провадження планованої діяльності, а також 
(за потреби) планів післяпроектного моніторингу». Одним 3 серйозних недоліків ОВД для Добротвірської МГЕС $є$ також відсутність в ньому результатів прогнозування потенційно можливої гідродинамічної аварії на існуючих напірних гідроспорудах Добротвірського водосховища при будівництві МГЕС, з оцінкою ймовірності аварії за різними сценаріями іiі виникнення та ризику можливих наслідків за різними сценаріями іiі розвитку. Добротвірську МГЕС планується споруджувати у складі вже діючого гідровузла. Це, звичайно, слід розглядати як позитивний момент з точки зору раціоналізації природокористування. Однак, розміщення будівлі МГЕС в межах існуючої напірної гідроспоруди (земляної греблі), що формує напірний фронт Добротвірського гідровузла, викликає певні занепокоєння. Відповідно до Закону України «Про об’єкти підвищеної небезпеки» [14] та Методики [15] Добротвірський гідровузол є потенційно небезпечним об'єктом. Проведення будівельних робіт, а в перспективі і експлуатація гідроспоруди МГЕС, можуть спровокувати аварію на гідровузлі 3 проривом напірного фронту (гідродинамічну аварію), наслідки якої можуть бути катастрофічними для довкілля, а також і для роботи Добротвірської ТЕС, яка використовує водосховище. Слід також зазначити, що Західний Буг, на якому розміщуються гідроспоруди Добротвірського гідровузла, є транскордонною річкою. Ці питання жодним чином не знайшли свого відображення в звіті.

Другу групу складають звіти, які за складом матеріалів переважно відповідають формальним вимогам Закону з ОВД. Втім, незважаючи на великий об'єм інформації в деяких 3 них (включно 3 додатками це сотні сторінок), в цих звітах також відсутні дані, які б дозволяли однозначно оцінити вплив планованої діяльності на довкілля та його наслідки.

Інформація про гідроспоруди та довкілля в цих звітах, яка може вважатися об'єктивною, носить здебільшого оглядовий характер і стосується не стільки впливу планованої діяльності на довкілля та його наслідків, скільки характеристики природних (кліматичних, гідрологічних, інженерногеологічних, гідрогеологічних тощо), екологічних та соціальних умов, які можуть вплинути на плановану діяльність, ускладнити ii чи заважати іiі проведенню. При цьому автори звітів часто зловживають підміною понять та власними суб'єктивними оцінками доцільності планованої діяльності для довкілля і місцевого населення, оперуючи неповною, спірною, перекрученою інформацією, що стосується впливів малої гідроенергетики на довкілля. Інформація про вплив на довкілля об'єктів малої гідроенергетики, що подається в звітах, не завжди відповідає дійсності і може вводити в оману громадськість, підводячи людей, що не є фахівцями, до хибних висновків, що планована діяльність має обов'язково здійснюватися, щоб покращити стан довкілля, вирішити місцеві соціально-економічні проблеми тощо.

Так, наприклад, «значно нижчі питомі експлуатаційні витрати ... і більш тривалі терміни експлуатації ...» (звіти з ОВД будівництва двох МГЕС на p. Шопурка в смт Кобилецька Поляна від «НП «Експертний Центр») не можуть розглядатися як позитивні екологічні чинники, навіть опосередковано. Це економічні категорії, які можуть зацікавити лише інвестора. Недоречними в звітах є і посилання (своєрідне «переведення стрілок») на «більш актуальні і критичні» проблеми регіону, такі, наприклад, як «вирубування лісів» тощо. Порушення в одній сфері, одними особами, не можуть виправдовувати можливі порушення в іншій сфері, іншими особами. 
В якості прикладу дещо упередженого висновку на користь планованої діяльності (будівництва ще двох МГЕС на р. Шопурка біля смт В. Бичків), може слугувати наступний висновок в звітах від ІФНТУНГ та УжНУ: «Таким чином, хоча на даному етапі проекту не всі екологічні наслідки планованої діяльності можуть бути оцінені, характер і масштаби цієї діяльності дозволяють констатувати, що негативні впливи на довкілля мають характер дуже обмежений у просторі і часі та не спричиняють наслідків на населення і природне середовище, які вимагають додаткового втручання чи реагування 3 метою їх пом'якшення чи усунення». Цей висновок було зроблено за матеріалами вже першого розділу поданих звітів з ОВД, де, згідно з Законом про ОВД, має даватися загальний опис планованої діяльності та основних іiі характеристик. Цим висновком, в принципі, заперечується необхідність подальшого дослідження можливих впливів планованої діяльності та їх наслідків, формулювання рекомендацій щодо їх пом'якшення чи усунення.

При цьому в жодному 3 проаналізованих нами звітів 3 ОВД відсутні зауваження «незалежних» «експертів», пов'язані з розглядом невластивих чи несуттєвих для проектів загроз, небезпек та масштабів негативних наслідків впливу будівництва та експлуатації тієї чи іншої МГЕС на довкілля, або ж ігнорування корисних ефектів, які виправдовують доцільність проектів. Тобто перебільшень негативних впливів, які б зашкодили іміджу планованої діяльності, в звітах з ОВД нема.

В той же час при ОВД об'єктів малої гідроенергетики «незалежні» «експерти», свідомо чи несвідомо, але не враховують вимоги, які записані в чинних будівельних нормах (див. ДБН В.2.4-3:2010. Гідротехнічні, енергетичні та меліоративні системи і споруди, підземні гірничі виробки. Гідротехнічні споруди. Основні положення [16]). Зауважимо, що ці норми «... поширюються на проектування, ..., гідротехнічних споруд усіх видів і класів», a їх вимоги «...обов'язкові до застосування проектновишукувальними, будівельними та експлуатаційними організаціями, організаціями управління, контролю і експертизи всіх рівнів». I, що головне, ці вимоги жодним чином не суперечать Закону з ОВД [9].

Зокрема, в ДБН В.2.4-3:2010 [16] (див. п. 1.2.8) вказується, що для вирішення природоохоронних питань при проектуванні, будівництві та експлуатації гідротехнічних споруд, в чому числі і МГЕС, розроблення природоохоронних заходів, необхідно робити оцінку і прогнозування:

- зміни геологічних і гідрогеологічних умов - рівневого режиму, умов живлення, забруднення підземних вод, особливо мінералізованих, засолення грунтів;

- фільтраційних втрат води з водоймищ через дно і береги;

- змін природного стану в результаті створення водоймищ; термічного і льодового режимів у б’єфах, у тому числі утворення протяжних полинів, посилення заторно-зажорних явищ;

- зміни ходу руслового процесу, трансформації русла нижніх б'єфів, замулення водоймищ і переробки берегів; ландшафту району будівництва i його відновлення;

- впливу змін руслового, гідравлічного, термічного і льодового режимів водотоків і водоймищ на умови нересту і відтворення риб, гніздування птахів, середовища перебування тварин тощо; впливу мікрокліматичних змін у районі створення водоймищ і нижнього б'єфу гідровузла - температурного режиму і 
вологості повітря, кількості і режиму вітрів і опадів - на інженерно-геологічні процеси і властивості грунтів основ, а також на об'єкти інфраструктури i природне середовище.

У проаналізованих звітах з ОВД належні оцінки і прогнози цих змін та спровокованих ними явищ і процесів відсутні. Особливо актуальними в контексті тривалої експлуатації МГЕС (до 50 років) слід відзначити оцінку і прогнозування змін ходу руслового процесу, трансформації русла нижніх б’єфів, що повністю ігнорується при ОВД МГЕС. Саме зміни ходу руслового процесу, трансформація русел викликають гідроморфологічні зміни, зазвичай негативні і практично незворотні, русел річок, які, зрештою, і призводять до деградації екологічного статусу малих та середніх річок [17].

Якщо посилатися на формальні вимоги Закону з ОВД [9], то в звітах з ОВД слід представити «опис і оцінку можливого впливу на довкілля планованої діяльності, зокрема величини та масштабів такого впливу (площа території та чисельність населення, які можуть зазнати впливу), характеру (за наявності транскордонного), інтенсивності і складності, ймовірності, очікуваного початку, тривалості, частоти і невідворотності впливу (включаючи прямий i будь-який опосередкований, побічний, кумулятивний, транскордонний, короткостроковий, середньостроковий та довгостроковий, постійний i тимчасовий, позитивний і негативний вплив)...».

В проаналізованих нами звітах з ОВД МГЕС подібні оцінки і прогнози належним чином не виконувались.

Зокрема, оскільки тривалість експлуатації МГЕС передбачається до 50 років, то впливи планованої діяльності на довкілля та їх наслідки мали б аналізуватися й оцінюватися і з врахуванням змін в часі, тобто, при ОВД МГЕС мали б складатися як мінімум по три прогнози для різних факторів впливу: короткострокові (на перші кілька років експлуатації гідроспоруд), середньострокові (наприклад, через 10-20 років експлуатації гідроспоруд) та довгострокові (на кінець заявленого терміну експлуатації МГЕС).

При цьому громадськості для ознайомлення надаються звіти-кальки з ОВД МГЕС, які готувалися однією і тією ж організацією для різних об'єктів (наприклад, звіти для різних МГЕС на р. Шопурка). Подекуди ці звіти мають ще й надзвичайно великий об'єм (до 700 сторінок тексту, 3 додатками, як, наприклад, звіти з ОВД, підготовлені ПБМП «Строїтель-ІІ»). В звіт з ОВД може включатись і інформація, яка взагалі не стосується об'єкта досліджень, як, наприклад, в звіті з ОВД будівництва МГЕС на р. Стрий біля с. Довге в Львівській обл. було наведено численні фотографії, якими ілюструється хід будівництва ГЕС за кордоном.

Вкрай незадовільно, на нашу думку, в звітах подається представлення та аналіз виправданих альтернатив планованої діяльності. Зокрема, в якості виправданих технічних альтернатив МГЕС розглядають будівництво ТЕС чи AEC (чому, наприклад, не СEC чи ВEC?). Більш доцільно, в цьому випадку, в якості технічних альтернатив розглядати і варіанти заходів, спрямованих на запобігання, відвернення, уникнення, зменшення, усунення негативного впливу на довкілля (наприклад, різні схеми облаштування рибоходів), аніж способи підвищення ефективності господарчої діяльності інвестора (вибір гідроенергетичного обладнання з вищим ККД тощо).

Те ж саме стосується і територіальних альтернатив. Якщо вони й розглядаються, то при цьому переслідується лише мета отримання більшого 
прибутку: «потреба у наявності перепадів висот та достатніх об' ємів річкового стоку для вироблення електроенергії з відновлюваних джерел; запропоноване розташування МГЕС має добре автомобільне сполучення, що є зручним для будівництва» (таке пояснення, наприклад, дається в звітах 3 ОВД, підготовлених в ІФНТУНГ для двох МГЕС на р. Шопурка). Територіальні альтернативи можуть і взагалі не розглядатися, як, наприклад, в звітах з ОВД для трьох МГЕС на р. Тересва.

В той же час, для об'єктивності ОВД представлення і опис виправданих альтернатив, як технічних, так і територіальних, є надзвичайно важливим. Зрештою, через альтернативи показується чи виважено забудовник-інвестор ставиться до охорони довкілля та раціонального природокористування. В свою чергу виконавець ОВД має зробити хоча б якусь їх оцінку (якісну, типу SWOTаналізу, чи кількісну, як, наприклад, пропонується в [18]), задавшись критерієм оптимальності, визначивши цільову функцію й виконавши попарне порівняння альтернатив тощо. Це слід робити, щоб заявлені «вигоди» i «переваги» вибраної альтернативи не були голослівними, та для формального підтвердження доцільності планованої діяльності. В будь-якому разі, для обгрунтування причин обрання запропонованого варіанта 3 врахуванням екологічних наслідків мають наводитися конкретні аргументи, які б засвідчували екологічність прийнятого варіанту в порівнянні 3 іншими варіантами, а не інформація загального характеру, подібна до передвиборчих лозунгів. Наведена в звітах інформація щодо «планованої діяльності як виправданої альтернативи» має стосуватися і цілком конкретних МГЕС, які планується побудувати в цілком конкретних створах і на конкретній річці, в порівнянні з конкретними альтернативами, з відповідними аргументами.

Наприклад, в звітах з ОВД щодо будівництва двох МГЕС на р. Шопурка, біля смт Великий Бичків (розроблених у ІФТУНГ), в якості аргументу на користь вибраної альтернативи спочатку стверджується те, що «дериваційні ГЕС вважаються більш екологічно безпечними порівняно 3 русловими ГЕС», оскільки для цього не потрібно будувати великі водосховища, а потім, щоб продемонструвати позитиви «співіснування об'єктів гідроенергетики та природних угідь охоронюваного статусу», вже йде посилання на безумовну користь спорудження великих водосховищ, які «органічно вписуються в існуючі природні комплекси», «покращують умови водопостачання, рибного господарства, протиповеневого захисту, екологічні умови у меженний період ...». При цьому, для підтвердження таких висновків використовуються звіти з ОВД на цій же річці, які було розроблено іншою організацією (НП «Експертний Центр»), де, в свою чергу, в якості аргументу використовуються приклади закордонних об'єктів, які жодним чином, ні за природними умовами, ні функціонально, ні структурно, не можуть порівнюватися з планованими МГЕС на р. Шопурка.

В дискусійному порядку висловимо окрему думку щодо «екологічності» дериваційних ГЕС. Дериваційна схема за жодних умов, тобто, якими б не були при цьому тип чи конструкція дериваційного тракту, не працюватиме на побутовому стоці в екологічному розумінні проблеми. Дериваційна схема передбачає відбір води з природного русла в дериваційний канал (або тунель, трубу), що є штучними водотоками. Деривація не допускає жодної можливості для ii використання гідробіотою в якості водного шляху між б'єфами. Це фактично мертве русло, навіть якщо це відкритий канал, який, звичайно, 
виглядає більш естетично, ніж, наприклад, труба на опорах або природне русло практично без води (див. рис. 1). Особливістю дериваційних ГЕС є також розосередженість основних гідроспоруд в просторі. Не варто вводити громадськість в оману, наголошуючи на тому, що дериваційна схема - це завжди більш екологічна схема, ніж руслова чи пригребельна ГЕС.

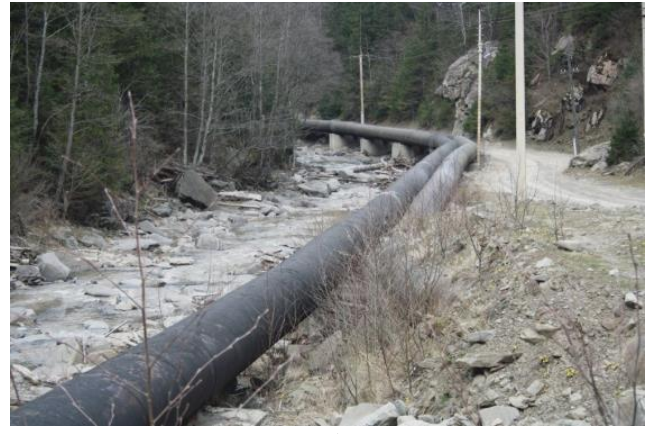

a)

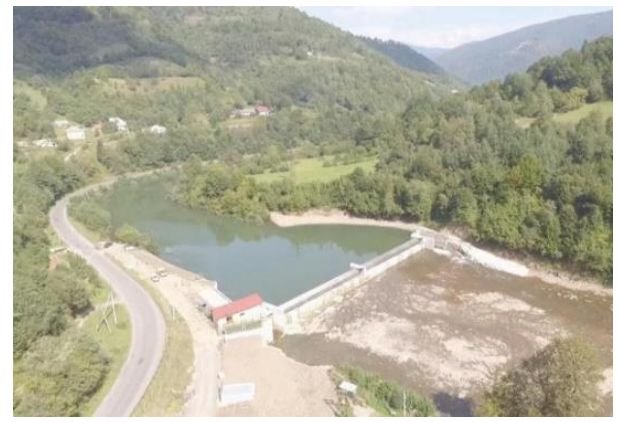

б)

Рис. 1 - Приклади виконання деривації на МГЕС, побудованих в Українських Карпатах: а) відкрита труба на опорах вздовж русла р. Чорний Черемош на Пробійнівській ГЕС-1 (Фото - WWF); б) осушене русло р. Ріка в нижньому б'єфі греблі Нижньобистрівської МГЕС при закритій деривації

(заритій трубі) (Фото - О. Станкевич-Волосянчук)

Що стосується наведених в звітах прикладів успішного «співіснування об'єктів гідроенергетики та природних угідь охоронюваного статусу», більш доречно було б демонструвати це на вітчизняних прикладах. Щодо наведених прикладів з зарубіжного досвіду, то варто було б при цьому також зазначати, що більшість 3 них відносяться до випадків створення національних природних парків на базі вже існуючих водосховищ, тобто, що дуже важливо, не до будівництва гідровузлів, що мають у своєму складі гідроелектростанції, а вже після їх будівництва, тобто в період експлуатації.

Некоректно в звітах з ОВД для виправдання планованої діяльності, що стосується МГЕС, звинувачувати в існуючих екологічних проблемах місцеве населення та «неорганізовані туристичні групи». Наприклад, це зроблено в звітах, підготовлених в ІФНТУНГ та УжНУ: «Для річки Шопурки та місця планової діяльності найбільші загрози в цьому аспекті (тобто екологічному) створює населення с. Кобилецька Поляна та частково і смт В. Бичкова». Необгрунтованими $є$ i твердження, що «погіршення основних соціальнопобутових умов життєдіяльності населення внаслідок планової діяльності не очікується», оскільки «діяльність планового об'єкта сприятиме покращенню соціально-економічного стану регіону». Місцеве і регіональне - це не одне і теж, коли мова йде про гідроенергетику. Це ситуація, коли прибутком або вигодами може користуватися одна частина суспільства (у випадку МГЕС - це обмежена кількість осіб, що можуть проживати i на іншій територіï), а ризикувати - місцева громада, що, зрештою, і породжуватиме конфлікт. В світовій практиці були випадки, коли гідроенергетичні об'єкти безумовно сприяли соціально-економічному розвитку регіонів, навіть цілих країн, але при цьому завдавалась непоправна шкода життєдіяльності місцевого населення, усталеному способу життя місцевих жителів [19, 20]. 
Окремим питанням є подання в звітах з ОВД МГЕС гідрологічних даних та їх трактування. Якщо дослідити поточний екологічний стан довкілля можна i за порівняно короткий відрізок часу (протягом одного-двох років), то об'єктивно оцінити гідрологічні особливості річки без належних і тривалих гідрологічних спостережень практично неможливо. В той же час прорахунки в гідрологічному та водноенергетичному обгрунтуваннях гідроенергетичного проекту багато в чому визначають те, наскільки масштабним може виявитися вплив планованої діяльності на довкілля.

В більшості звітів з ОВД для МГЕС використовуються або недостатні, або застарілі даних гідрологічних спостережень. Так, наприклад, гідрологічні дані, що використовувалися при обгрунтуванні рішень щодо дев'яти МГЕС на p. Шопурка i, зокрема, при «оцінці поточного стану довкілля (базовий сценарій)», хоча i були визначені «за наявними даними гідропоста біля смт Кобилецька Поляна за багаторічний період ...», але цей період зафіксовано « ... 31954 р. по 1988 р.». Цілком вірогідно, що за останні тридцять років гідрологія р. Шопурка могла зазнати змін, в першу чергу в характеристиках екстремального (максимального та мінімального) стоку, і ці зміни мали б дослідитися. Це особливо актуально, якщо виходити 3 припущення, що на водність малих річок значний вплив має діяльність людини та кліматичні зміни. Відповідно, слід обгрунтовувати як правомірність використання при прогнозуванні гідрологічних характеристик відповідних законів розподілу ймовірності, так і власне самої математичної моделі гідрологічного явища, представленої у вигляді закону розподілу ймовірності.

У цьому зв'язку повною нісенітницею є криві розподілу ймовірності, які наводяться в деяких звітах (див. приклад на рис. 2).

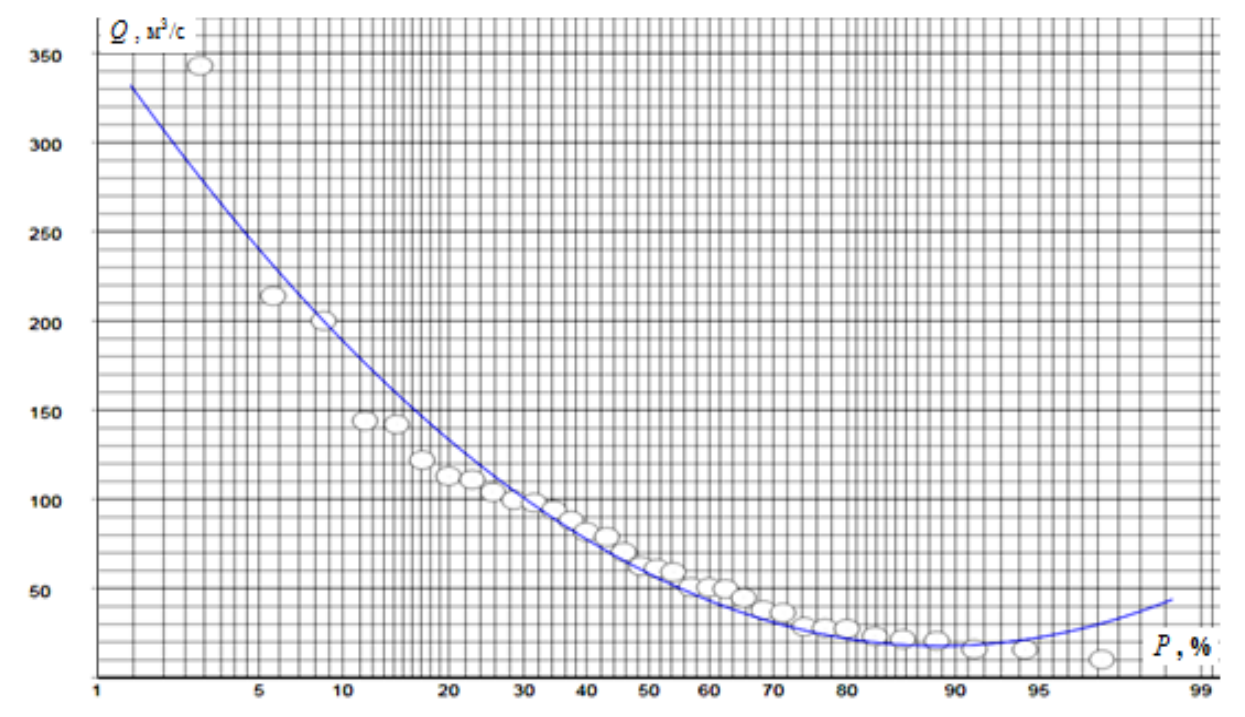

Рис. 2 - «Крива забезпеченості» максимальних витрат води паводків за холодний період р. Шопурка (с. Кобилецька Поляна) за версією НП «Експертний Центр» (директор Л.П. Крадожон)

Подібні картинки $з$ дивними кривими забезпеченості витрат води, як та, яку в якості ілюстрації показано вище на рис. 2, наведено і в звіті з ОВД 
будівництва МГЕС на р. Стрий біля с. Довге, у Львівській обл. Тим не менше, ці три звіти було прийнято до розгляду і на них було дано позитивні висновки щодо можливості провадження планованої діяльності з боку уповноважених органів, як центрального (відділ оцінки впливу на довкілля колишнього Мінприроди України), так i територіального (департамент екології та природних ресурсів Львівської ОДА), відповідно.

\section{Деякі практичні пропозиції щодо підвищення якості ОВД для МГЕС}

Окрім висловлених вище в тексті статті критичних зауважень, зупинимось і на деяких практичних пропозиціях, реалізація яких могла б посприяти підвищенню якості проведення ОВД в малій гідроенергетиці.

Важливе значення для підвищення об'єктивності і якості ОВД може мати об'єм та форма представлення інформації. Зокрема, для зручності сприйняття й перевірки інформації, і для того щоб не виникало підозр в наданні громадськості «неправдивих чи неповних відомостей про вплив на довкілля планованої діяльності», в звітах з ОВД варто наводити наступні дані:

- карти затоплень територій в верхніх б’єфах гідроспоруд, в тому числі і вірогідних додаткових затоплень, спричинених підвищенням відміток дна внаслідок відкладання наносів, та ймовірних затоплень внаслідок заторнозажорних явищ при проходженні паводків різної забезпеченості тощо;

- карти ймовірних затоплень при гідродинамічних аваріях, що, зокрема, можуть відбуватися не лише внаслідок «підриву ГЕС», а й в результаті руйнування будь-якої іншої напірної споруди у складі напірного фронту, наприклад, при проривах захисних дамб; при цьому на перебіг гідродинамічної аварії може впливати накладання природного і штучного паводків, проривний потік може міняти напрямок руху тощо;

- карти вірогідного підтоплення територій, абразійної переробки берегів, ймовірного поширення заторно-зажорних явищ та прогнозованих гідроморфологічних змін (донної та берегової ерозії, відкладення наносів та продуктів розмиву русла і берегів вниз за течією) тощо, з позначенням ділянок їх інтенсифікації, з розвитком в просторі та часі.

Такі карти наглядно продемонструють вищеперераховані впливи на довкілля від експлуатації МГЕС та їх наслідки, в тому числі і в часі (наприклад, для короткострокової, середньострокової та довгострокової перспективи, на початок та на кінець можливої інтенсифікації чи затухання негативних процесів). Причому в багатьох випадках тут мова йде про ті впливи на довкілля i ïx наслідки, що можуть мати i безпосереднє значення для безпеки життєдіяльності місцевих жителів.

\section{Висновки}

За результатами проведеного аналізу ряду звітів з ОВД, розроблених для об'єктів малої гідроенергетики різними суб'єктами господарювання, можна зробити наступні висновки.

Найбільш важливі для об'єктивної оцінки впливу планованої діяльності на довкілля розділи представляються в звітах з ОВД неналежним чином. Серед них: опис виправданих альтернатив (Розділ 2); опис поточного стану довкілля (базовий сценарій) та опис його ймовірної зміни без провадження планованої 
діяльності (Розділ 3); опис факторів довкілля, які ймовірно зазнають впливу 3 боку планованої діяльності та іiі альтернативних варіантів (Розділ 4); опис і оцінка можливого впливу на довкілля планованої діяльності (Розділ 5) (в цьому розділі в звітах практично немає жодних прогнозів щодо негативних змін); опис методів прогнозування, що використовувалися для оцінки впливу на довкілля, та припущень, покладених в основу такого прогнозування, а також використовувані дані про стан довкілля (Розділ 6); опис передбачених заходів, спрямованих на запобігання, відвернення, уникнення, зменшення, усунення значного негативного впливу на довкілля (Розділ 7); опис очікуваного значного негативного впливу діяльності на довкілля (Розділ 8) (особливо в питаннях прогнозування аварійних та надзвичайних ситуацій, в тому числі і екологічно-конфліктних ситуацій).

За формальними ознаками звіт з ОВД може і відповідати Закону з ОВД. В звіті з ОВД можуть бути представлені (або згадані) всі необхідні розділи, щоб відповідати формальним вимогам Закону. Втім, за суттю цих розділів звіт не може вважатися прийнятним, якщо наведена в них інформація не дозволяє об' єктивно оцінити всі небезпеки проекту. Зрештою, процедура ОВД повинна мати за мету виявити і дослідити те, чим може зашкодити річці і місцевому населенню «планована діяльність», щоб мінімізувати цю шкоду, а не те, що може зашкодити проведенню «планованій діяльності».

\section{СПИСОК ЛІТЕРАУРИ}

1. Мала гідроенергетика світу. URL: https://msd.in.ua/mala-gidroenergetika-svitu/.

2. Власюк Ю.С., Стефанишин Д.В. Про проблеми та перспективи малої гідроенергетики в Україні. Математичне моделювання в економіці. № 1 (10). 2018. C. 126-138.

3. Васько П.Ф., Васько В.П., Ібрагімова М.Р. Мала гідроенергетика в структурі електроенергетичної галузі України. Відновлювана енергетика. 2015. № 3. С. 53-61.

4. Інформація щодо потужності та обсягів виробництва електроенергії об'єктами відновлюваної електроенергетики, яким встановлено «зелений» тариф (станом на 30.09.2018). 4 c. URL: http://saee.gov.ua/sites/default/ files/VDE.pdf.

5. 3 початку року в «зелену» енергетику інвестовано понад 2 мільярди євро. URL: https://www.epravda.com.ua/news/2019/10/7/652329/.

6. Стефанишин Д.В., Власюк Ю.С. До питання порівняльного аналізу водноенергетичних характеристик малих і великих гідроелектростанцій України у складі гідровузлів з водосховищами. Математичне моделювання в економіці. № 2. 2018. C. $71-83$.

7. Оржель О. Малі ГЕС: зло чи благо? Великі монополії грають без правил проти представників передових технологій, які становлять для велетнів серйозну загрозу недоотримання надприбутків. 16 жовтня 2015. URL: https://www.epravda.com.ua/ columns/2015/10/16/563528/?fbclid=IwAR0M0qcj9ILo7-vQUUB6m0N_xSYFmky_xXO 6au96_Q2GqHYDV6926yvE498.

8. Позиція Всесвітнього фонду природи WWF щодо розвитку малої гідроенергетики в Україні. 2018. URL : http://wwf.ua/materials/official/?uNewsID=323990.

9. Про оцінку впливу на довкілля: Закон України № 2059-VIII від 23.05.2017. Офіиійний вісник України. 2017. №50. С. 5. Відомості Верховної Ради (ВВР), 2017, № 29, ст. 315. URL : http://zakon.rada.gov.ua/laws/show/2059-19.

10. Розвиток теплоенергетики та гідроенергетики / Є.Т. Базеєв, Б.Д. Білека, Є.П. Васильєв та ін.; Наук. ред. В.М. Клименко, Ю.О. Ландау, І.Я. Сігал. 2013. 399 с. URL: http://energetika.in.ua/ua/books/book-3/part-2/section-2/2-8. 
11. До 2020 року в Україні $11 \%$ енергії вироблятиметься 3 відновлюваних джерел. URL:http://ecotown.com.ua/news/Do-2020-roku-v-Ukrayini-11-enerhiyi-vyroblyatymetsyaz-vidnovlyuvanykh-dzherel/.

12. Огляд ситуації щодо гідроенергетики в Україні. URL: https://censor.net.ua/blogs/ 4415/oglyad_situats_schodo_gdroenegetiki_v_ukran.

13. Оцінка впливу на довкілля. Сдиний реєстр. URL: http://eia.menr.gov.ua/search.

14. Закон України «Про об’єкти підвищеної небезпеки». Відомості ВРУ. 2001. № 15.

Ст. 73. URL : https://zakon.rada.gov.ua/laws/show/2245-14.

15. Методика ідентифікації потенційно небезпечних об'єктів. Затверджена наказом МНС України від 23.02.2006 р. за № 98. Зареєстровано в Мінюстиції України від 20.03.2006 p. за № 286/12160. URL : http://zakon2.rada.gov.ua/ laws/show/z0286-06.

16. ДБН В.2.4-3:2010. Гідротехнічні, енергетичні та меліоративні системи і споруди, підземні гірничі виробки. Гідротехнічні споруди. Основні положення. Київ : Міністерство регіонального розвитку та будівництва України, 2010. 37 с.

17. Identification and Designation of Heavily Modified and Artificial Water Bodies. CIS Working Group 2.2. 10 December 2002. 11 p. URL : http://www.wrrl-info.de/docs/ HMWBpolicysummary101202.pdf.

18. Стефанишин Д.В. Обгрунтування оптимального сценарію введення нових агрегатів на гідроакумулюючих електростанціях в Україні 3 врахуванням ризику. Гідроенергетика Украӥни. №3-4. 2018. С. 24-29.

19. Ivashintsov D.A., Stefanishin D.V., Veksler A.B. Ecological and sociodemographic consequences of hydrotechnical construction (Problems of safety and risk). Power Technology and Engineering (formerly Hydrotechnical Construction). 1993. Vol. 27. Num. 12. P. 685-691.

20. Environmental experience gained from reservoirs in operation. Trans. of the 18-th Int. Cong. on Large Dams. Vol. 2. Q.69. Durban-South Africa, 1994. 780 p.

Стаття надійшла до редакиї 10.10.2019 і прийнята до друку після рецензування 06.11 .2019

\section{REFERENCES (TRANSLATED AND TRANSLITERATED)}

1. Small hydropower of the world. Retrieved from https://msd.in.ua/mala-gidroenergetikasvitu/. (in Ukrainian).

2. Vlasyuk, Yu.S., Stefanyshyn, D.V. (2018). On problems and prospects of small hydropower engineering in Ukraine. Mathematical Modeling in Economy, №1, 2018, 126138. (in Ukrainian).

3. Vasko, P.F., Vasko, V.P., Ibrahimova, M.R. (2015). Small hydropower in the structure of the electricity sector of Ukraine. Renewable energy, № 3, 53-61. (in Ukrainian).

4. Information on power and volumes of electricity produced by renewable energy objects, which have a "green" tariff (as of September 30, 2018). 4 p. Retrieved from http://saee.gov.ua/sites/default/files/VDE.pdf. (in Ukrainian).

5. Since the beginning of the year, over $€ 2$ billion has been invested in green energy. URL: https://www.epravda.com.ua/news/2019/10/7/652329/.

6. Stefanyshyn, D.V., Vlasyuk, Yu.S. (2018). To the issue of comparative analysis of waterenergy characteristics of small and large hydroelectric power plants of Ukraine being parts of waterworks with reservoirs. Mathematical Modeling in Economy, №2, 71-83. (in Ukrainian).

7. Orzel, O. (2015). Small HPSs: evil or good? Big monopolies play without rules against the representatives of advanced technology posing a serious threat to the giants which lose their over profits. October 16, 2015. Retrieved from https://www.epravda.com.ua/columns/ 2015/10/16/563528/?fbclid=IwAR0M0qcj9ILo7-vQUUB6m0N_xSYFmky_xXO6au96_Q 2GqHYDV6926yvE498. (in Ukrainian). 
8. WWF's position on the development of small hydropower in Ukraine. (2018). Retrieved from http://wwf.ua/materials/official/?uNewsID=323990. (in Ukrainian).

9. On Environmental Impact Assessment: Law of Ukraine No. 2059-VIII of 23 May 2017 Official Bulletin of Ukraine. (2017). №50. P. 5. Verkhovna Rada (BBR) Bulletin, No. 29, Art. 315. Retrieved from http://zakon.rada.gov.ua/laws/show/2059-19. (in Ukrainian).

10. Development of heat power engineering and hydropower. (2013). Baseev, Ye. T., Bileka, B. D., Vasiliev, Ye. P., et al.; Science ed. Klymenko, V. M., Landau, Yu. O., Sigal, I. Ya. 399 p. Retrieved from http://energetika.in.ua/ua/books/book-3/part-2/section2/2-8. (in Ukrainian).

11. By 2020, $11 \%$ of Ukraine's energy will be generated from renewable sources. Retrieved from http://ecotown.com.ua/news/Do-2020-roku-v-Ukrayini-11-enerhiyi-vyroblyatymetsyaz-vidnovlyuvanykh-dzherel/. (in Ukrainian).

12. Overview of the situation regarding hydropower in Ukraine. Retrieved from https: //censor.net.ua/blogs/4415/oglyad_situats_schodo_gdroenegetiki_v_ukran. (in Ukrainian).

13. Environmental Impact Assessment. Unified registry. Retrieved from http://eia.menr. gov.ua/search. (in Ukrainian).

14. Law of Ukraine “On Extremely Dangerous Objects”. (2001). VRU information. № 15. Art. 73. Retrieved from https://zakon.rada.gov.ua/laws/show/2245-14. (in Ukrainian).

15. Methods for identifying potentially dangerous objects. (2006). Approved by the order of the Ministry of Emergencies of Ukraine dated 23.02.2006 at № 98. Registered with the Ministry of Justice of Ukraine on 20.03.2006 at № 286/12160. Retrieved from http://zakon2.rada.gov.ua/ laws/show/z0286-06. (in Ukrainian).

16. DBN B.2.4-3: 2010. Hydrotechnical, energy and reclamation systems and structures, underground mining. Waterworks. Substantive provisions. (2010). Kyiv: Ministry of Regional Development and Construction of Ukraine, 37 p. (in Ukrainian).

17. Identification and Designation of Heavily Modified and Artificial Water Bodies. (2002). CIS Working Group 2.2. 10 December 2002. 11 p. Retrieved from http://www.wrrlinfo.de/docs/ HMWBpolicysummary 101202.pdf.

18. Stefanyshyn, D.V. (2018). Grounding the optimal scenario for the introduction of new aggregates at the hydroelectric power plants in Ukraine taking into account the risk. Hydropower of Ukraine, №3-4, 24-29. (in Ukrainian).

19. Ivashintsov, D.A., Stefanishin, D.V., Veksler, A.B. (1993). Ecological and sociodemographic consequences of hydrotechnical construction (Problems of safety and risk). Power Technology and Engineering (formerly Hydrotechnical Construction), Vol. 27, Num. 12, 685-691.

20. Environmental experience gained from reservoirs in operation. Trans. of the 18-th Int. Cong. on Large Dams. Vol. 2. Q.69. Durban-South Africa, 1994, 780 p.

The article was received 10.10.2019 and was accepted after revision 06.11.2019

\section{Стефанишин Дмитро Володимирович}

доктор технічних наук, провідний науковий співробітник Інституту телекомунікацій і глобального інформаційного простору НАНУ, професор кафедри гідротехнічного будівництва та гідравліки Національного університету водного господарства та природокористування

Адреса робоча: 33028 Україна, м. Рівне, вул. Соборна, 11

$\boldsymbol{e}$-mail: d.v.stefanyshyn@nuwm.edu.ua

ORCID: https://orcid.org/0000-0002-7620-1613

\section{Власюк Юрій Степанович}

аспірант Національного університету водного господарства та природокористування

Адреса робоча: 33028 Україна, м. Рівне, вул. Соборна, 11

e-mail: y.s.vlasiuk@nuwm.edu.ua

ORCID ID: https://orcid.org/0000-0002-6359-733X 